\title{
EPILEPTIC SEIZURES AS THE FIRST MANIFESTATION OF THE FRONTOPARIETAL ARTERIOVENOUS MALFORMATION OF THE BRAIN
}

\author{
Skrijelj E. Fadil, Mulic Mersudin \\ State University of Novi Pazar, Novi Pazar, Serbia
}

Primljen/Received 16. 04. 2019. god.

Abstract: Introduction: Arteriovenous malformations of the brain include a group of congenital disorders in the early development of arterial-venous blood vessels of the brain. Their clinical presentation is most common in the form of a brain hemorrhage, epileptic seizures, and headaches.

Case report: We showed a man who at the age of 28 early in the morning after breakfast had the first generalized tonic-clonic seizure. After the second unprovoked epileptic seizure, antiepileptic therapy was introduced. The brain scanner showed the existence of arteriovenous malformations in the right frontoparietal region. As the size of the malformation was less than $30 \mathrm{~mm}$, it was decided that the patient should be treated with Gamma knife radiosurgery. After the successful radiosurgery together with the antiepileptic drugs treatment, the patient is in a stable 1.5 year- long remission of epileptic seizures without neurological failures.

Conclusion: Epileptic seizures can be the initial clinical manifestations of arteriovenous malformations of the brain. With an early diagnosis, adequate antiepileptic drugs therapy and neurosurgery, radiosurgery (Gamma Knife), which is often necessary, many symptomatic epilepsies enter a stable remission of epileptic seizures.

Key words: arteriovenous malformations, brain, epileptic seizures, radiosurgery, gamma knife.

\section{INTRODUCTION}

Symptomatic epilepsies constitute a significant percentage of epilepsies in both the early and adult stages of human development, with vascular diseases of the brain (arteriovenous malformations, cavernomas, and aneurysms) being particularly significant. Arteriovenous malformations (AVM) of the brain represent a congenital disorder in the early differentiation of the development of arterial and venous blood vessels of
Prihvaćen/Accepted 19. 10. 2019. god.

the brain by establishing direct contact between the arteries and veins without the presence of capillaries (1). An AVM structurally consists of the pathological vascular web, the "nest" - nidus, which is composed of one or more supply arteries that continue on the main drainage vein and its collector branches. Because of this, an AVM shows a pathological tendency of frequent hemorrhages with deposits of hemosiderin in the surrounding brain tissue, which creates potential conditions for epileptogenesis, or the occurrence of epileptic seizures (2). By localization, AVMs are classified into supratentorial and infratentorial, superficial (cortical) and deep (subcortical) malformations. The main predictor factors for the assessment of operational risk for each AVM are localization, size and type of venous drainage (3). The most common effects of an AVM on surrounding brain structures are circulatory disorders in terms of microhemorrhage, the "steal" phenomena, the "mass" effects caused by the AVM size and its compression on adjacent structures with possible obstruction of the flow of liquors and the development of hydrocephalus (4). In the pathophysiological sense, an AVM among other things, causes "blood steal" ("the steal phenomena") in the adjacent regions of the brain, because normal blood flow is diverted within the AVM, thus bypassing the surrounding brain structures. This type of "blood steal" from the surrounding brain, with consecutive hypoperfusion, carries a high risk of epileptic seizures $(5,6)$. The predominant clinical manifestation of an AVM is brain hemorrhage (subarachnoidal, intracerebral, and intraventricular, or any combination thereof) (7). It is thought that about $50-70 \%$ of patients with an AVM experience brain hemorrhage. An average of $8 \%$ of subarachnoid hemorrhage (SAH) is caused by an AVM. AVM hemorrhage carries a risk of death in $10-15 \%$ of cases. It is thought 
that $15-20 \%$ of all sudden deaths are caused by an $\operatorname{AVM}(8,9,10)$. Crawford et al. 1986 (11), in their study of monitoring AVM patients for 20 years, found that the risk of hemorrhage was $42 \%$, epilepsy $18 \%$, neurological deficiency $27 \%$ and fatal outcome $29 \%$. The mortality rate in the initial hemorrhage of people with an AVM ranges from about $10 \%-15 \%$, and in aneurysm ruptures is about $50 \%(10)$. Epileptic seizures represent the second most common clinical manifestation of an AVM, more commonly seen in patients with severe malformations. Epileptic seizures are an initial symptom in $24-47 \%$ of patients with an AVM (11). The most common type of seizure is generalized motor seizures, ie focal seizure with generalization $(55.8 \%)$, then focal seizures without secondary generalization $(12,13)$. A superficially localized AVM is mainly clinically manifested by epileptic seizures, while the deep ones have a greater tendency to bleed (14). The dominance of focal seizures with generalization is the consequence of chronic cerebral hypoxia around the AVM and hemosiderin deposits caused by micro-hemorrhages. Headache is also a common clinical manifestation, and it appears as an initial symptom in the range of $5-35 \%$ of cases and results in an increase in pressure in the venous sinuses (15). Neurological deficiency occurs in about $27 \%$ of cases (11). The natural history of an AVM is that the patient has an annual risk of bleeding of $3 \%$, with a risk of developing an accompanying neurological deficiency of $35 \%$ and a fatal outcome of $10 \%$ (16).

AVM diagnostics is most commonly performed via computerized brain tomography (CT, MSCT), magnetic resonance imaging (MRI, MRA), and cerebral angiography (17). Computerized brain tomography, magnetic resonance imaging, and transcranial doppler (TCD) are considered to be basic non-invasive diagnostic methods for AVMs. There is a tendency in modern neurosurgery towards using non-invasive methods in AVM diagnostics, although the use of angiography is still dominant. The treatment of a brain AVM with antiepileptic drugs (AED) gives good results in more than $68 \%$ of cases and the refractoriness of epileptic seizures to AED was present in about $32 \%$ of cases. Generalized motorseizures are dominant in $94.7 \%$ of cases and focal seizures occur in $5.3 \%$ of cases. Good medication control of epileptic seizures supports the view that there is no need for emergency surgical treatment of an AVM. Treatment of an AVM with palliative methods is often ineffective in terms of reducing morbidity and healing (18). The surgical procedure leading to complete healing is complete excision of the AVM with noremaining residue $(19,20)$. Other neurosurgical methods are embolization and radiosurgery (focused gamma radiation-Gamma Knife) (21, 22). Post-operatively, in an AVM there is a decrease in the frequency of seizures in $14-54 \%$ of cases, while in
$7-22 \%$ of patients de novo epilepsy develops postoperatively (23). Patients who are deemed to carry a high risk of neurosurgical treatment of an AVM (resection, embolization or radiosurgery) are subject to drug treatment.

\section{CASE REPORT}

We showed a patient, aged 28, who reported to the neurologist due to the onset of the first epileptic generalized tonic-clonic (GTK) seizure. The seizure took place in the morning after breakfast and was not followed by prodromes or focal symptomatology. There was a sudden loss of consciousness with a fall and occurrence of GTK spasms and urination. After 2-3 minutes of the seizure, the patient regained his consciousness, felt heaviness in his body, exhaustion and nausea. He was healthy in the previous few days, he did not have headaches, and did not suffer from nervousness or insomnia. The vital signs upon admission were: blood pressure $120 / 80 \mathrm{mmHg}$, cardiac frequency $80 / \mathrm{min}$, body temperature $36.7^{\circ} \mathrm{C}$. There were no abnormalities in the neurological findings. The values of routine biochemical and laboratory analyses of serum (glycemia, Er, Hgb, Le, ESR, urea, creatinine, bilirubin, transaminases, total proteins, albumin, $\mathrm{Na}, \mathrm{K}, \mathrm{Mg}, \mathrm{Ca}$ ) and urine were within reference limits. There was no evidence of previous epileptic seizures or hereditary epilepsy. Electroencephalography (EEG), which was performed on the day of the seizure, resulted in normal findings, ie epileptiform graft elements were not registered. Since it was the first unprovoked seizure with normal EEG findings, antiepileptic therapy was not included. A month after the onset of the first GTK seizure, a second epileptic seizure occurred, the same clinical manifestation lasting 3-5 minutes. An EEG recording was performed and did not register epileptic activity. The patient then had a CT, CTA of the brain that showed the presence of a $25 \mathrm{~mm}$ arteriovenous malformation in the right frontoparietal region (Clinic of neurosurgery in Belgrade, Serbia). The therapy includes AED valproate at an initial dose of $0+0+250 \mathrm{mg} /$ day, with a gradual increase in the dose of $250 \mathrm{mg}$ per week, to an effective dose of $500+0+500 \mathrm{mg} /$ day. The patient was subjected to neurosurgical treatment and then, due to the size of the AVM $(<30 \mathrm{~mm})$, it was decided to carry out a Gamma Knife radiosurgery (Acibadem hospital in Istanbul, Turkey). On the first day after radiosurgery, another GTK seizure occurred during sleep, and the EEG recorded focal spikes and theta waves on the right frontoparietal without propagation to the homologous region of the opposite hemisphere. The dose of valproate was increased to $500+0+1000 \mathrm{mg} /$ day after which there were no further seizures. The patient is in a stable 1.5-year remission of epileptic seizures, 
without neurological failures and with regular neurosurgical and epileptologist examinations.

\section{DISCUSSION}

Arteriovenous malformations of the brain represent a congenital disorder in the early differentiation in the development of arterial and venous blood vessels of the brain. Due to their size, bleeding tendency and supratentorial localization often cause symptomatic epileptic seizures of the generalized or focal type. Epileptic seizures are treated with AED, but since they are symptomatic seizures associated with an AVM, they are usually drug-resistant (24). When an AVM is proven to cause epileptic seizures, neurosurgery, ie radiosurgery is indicated. Gamma Knife is stereotactic radiosurgery for the treatment of tumors and brain metastases (benign and malignant) which are smaller than $30 \mathrm{~mm}$ and well limited. It is performed without general anesthesia, without opening the skull, lasting from 30 minutes to $2 \mathrm{~h}$, and after the treatment, the patient can go home the same day or the next day. Gamma Knife directs radiation to a focussed pathological spot in the brain that is computer-determined so that gamma rays destroy the tumor tissue with the maximum sparing of surrounding healthy tissue. Earlier, since there was no Gamma Knife, even in the case of a small tumor, the whole brain was radiated. Our case report shows that epileptic seizures can be the first symptom of a brain AVM and that Gamma knife treatment together with AED (before and after treatment) leads to a complete remission of epileptic seizures. Our case report confirms works from the literature that Gamma Knife neurosurgery may be a prominent alternative to the treatment of brain AVM $(25,26)$. Most neurosurgical studies indicate that the main predictor of post-radiation epileptic seizures is the existence of an AVM nidus residue after the treatment (27). Thus, the primary goal of stereotactic radiotherapy is the complete obliteration of the AVM nidus, which ensures the conditions for a complete remission of epileptic seizures and gradual elimination of anti-epileptic drugs (28).

\section{CONCLUSION}

Epileptic seizures can be the initial clinical manifestations of arteriovenous malformations of the brain. With an early diagnosis (CT, MRI, EEG), adequate antiepileptic drugs therapy and Gamma Knife radiosurgery, which is often necessary, a complete remission of epileptic seizures is established in most patients, and the use of antiepileptic drugs is stopped. Using this procedure and treatment, many symptomatic epilepsies enter a stable remission of epileptic seizures.
Abbreviations
AVM - arteriovenous malformations
SAH - subarachnoid hemorrhage
GTC - generalized tonic-clonic
AED - antiepileptic drug
EEG - electroencephalography
CT - computed tomography
MSCT - multi-slide computer tomography
MRI - magnetic resonance image
MRA - magnetic resonance angiography
TCD - transcranial doppler

Conflict of Interests: The authors declare that there are no conflicts of interest related to this article.

Funding: None

\section{Licensing}

This work is licensed under a Creative Commons Attribution 4.0 International (CC BY 4.0) License.

\title{
Sažetak
}

\section{EPILEPTIČKI NAPAD KAO PRVA MANIFESTACIJA FRONTOPARIJETALNE ARTERIOVENSKE MALFORMACIJE MOZGA}

\author{
Skrijelj E. Fadil, Mulic Mersudin \\ Državni univerzitet u Novom Pazaru, Novi Pazar, Srbija
}

Uvod: Arteriovenske malformacije mozga obuhvataju grupu kongenitalnih poremećaja ranog razvoja arterijsko-venskih krvnih sudova mozga. Njihova klinička prezentacija se najčešće javlja u vidu moždanog krvarenja, epileptičkih napada i glavobolje. Prikaz bolesnika: Prikazali smo muškarca koji je u 28 godinini starosti u jutarnjim satima, nakon doručka, imao prvi generalizovani toničko-klonički epileptički napad. Na- kon drugog neprovociranog epileptičkog napada uvedena je antiepileptička terapija. Skener mozga je pokazao postojanje arteriovenske malformacije u desnom fronto-parijetalmom regionu. Kako je veličina malformacije bila manja od $30 \mathrm{~mm}$ odlučilo se za radiohiruško lečenje gama nožem (gamma knife). Nakon uspešno sprovedene stereotaksične radiohiruške terapije uz antiepileptičke lekove pacijent je u stabilnoj 1,5 g. re- 
misiji epileptičkih napada i bez neuroloških ispada. Zaključak: Arteriovenske malformacije mozga mogu se manifestovati epileptičkim napadom kao inicijalnim kliničkim znakom. Ranom dijagnozom, adekvatnom antiepileptičkom medikamentoznom terapijom i često

\section{REFERENCES}

1. Gault J, Sarin H, Awadallah NA, Shenkar R, Awad IA. Pathobiology of human cerebrovascular malformations: basic mechanisms and clinical relevance. Neurosurgery. 2004; 55(1): 1-17.

2. Fleetwood IG, Steinberg GK. Arteriovenous malformations. Lancet. 2002;359 (9309): 863-73.

3. Spetzler RF, Martin NA. A proposed grading system for arteriovenous malformations of the brain. J Neurosurg. 1986; 65(4): 476-83.

4. Constantino A, Vinters HV. A pathologic correlate of the ,steal" phenomenon in patients with cerebral arteriovenous malformation. Stroke. 1986; 17(1): 103-6.

5. Murphy JP. Cerebrovascular disease. Chicago: Year Book; 1954. p. 242-62.

6. Vates EG, Lawton MT, Wilson CB, Dermot MW, Halbach VV, Roberts TPL, et al. Magnetic source imaging demonstrates altrered cortical distribution of function in patients with artheriovenous malformations. Neurosurgery. 2002; 51(3): 614-27.

7. Perret G, Nishioka H. Report on the cooperative study of intracranial aneurisms and subarachnoid hemorrhage. Section VI. Arteriovenous malformations. An analysis of 545 cases of cranio-cerebral arteriovenous malformations and fistulae reported to the cooperative study. J Neurosurg. 1966; 25(4): 467-90.

8. Foster DMC, Steiner L, Hakanson S. Arteriovenous malformations of the brain. A long-term clinical study. J Neurosurg. 1972; 37(5): 562-72.

9. Parkionson D, Bachers G. Arteriovenous malformations. Summary of 100 consecutive supra-tentorial cases. J Neurosurg. 1980; 53(3): 285-99.

10. Drake CG. Progress in cerebrovascular disease. Management of cerebral aneurysm. Stroke. 1981; 12(3): 273-83.

11. Crawford PM, West CR, Chadwick DW, Slaw MD. Arteriovenous malformation of the brain: Natural history in unoperated patients. J Neurol Neurosurg Psychiatry. 1986; 49(1): 1-10.

12. Turjman F, Massoud TF, Sayre JW, Vinuela F, Guglielmi G, Duckwiler G. Epilepsy associated with cerebral arteriovenous malformations. J Neurradiol. 1995; 16(2): 343-50.

13. Pilarska E, Lemka M. Epileptic seizures in the vascular malformation in children. Przegl Lek. 2006; 66(1): 50-5.

14. Pellettieri L. Surgical versus conservative treatment of intracranial arteriovenous malformations. Acta Neurochir. 1979; 29: 11-36.

15. Su HT, Chen KB, Liu YC, Poon KS, Wa RS. Cerebral arteriovenous malformation diagnosed during labor induction with headache and convulsiones as presentations - a case report. Acta Anesthesiol Taiwan. 2005; 43(4): 247-51.

\section{Correspondence to/Autor za korespondenciju}

Fadil E. Skrijelj, MD PhD

State University of Novi Pazar

str V. Karadzica bb, 36300 Novi Pazar, Serbia

e-mail: skrijeljneuro@gmail.com

tel: +38163687743 nephodnim neurohiruškim, odnosno, radiohiruškim tretmanom (gama nož), mnoge simptomatske epilepsije ulaze u stabilnu remisiju epileptičkih napada.

Ključne reči: arteriovenske malformacije, mozak, epilepsija, napadi, radioiohirurgija, gama nož.

16. Kondziolka D, Mc Laughlin MR, Kestle JRW. Simple Risk Predictions for Arteriovenous Malformation Hemorrhage. Neurosurgery. 1995; 37(5): 851-5.

17. Al-Shahi R, Pal N, Lewis SC, Bhattacharya JJ, Sller RJ, Warlow CP. Observer agreement in the angiographic assessment of arteriovenous malformations of the brain. Stroke. 2002; 33(6): 1501-8.

18. Heros RC, Korosue K, Diebold PM. Surgical excision of cerebral arteriovenous malformations: Late results. Neurosurgery. 1990; 26(4): 570-8.

19. Janičijević M, Rakić M, Đorđić-Vujotić Lj. Hirurgija arteriovenskih malformacija mozga. Chirurgia Urgens. 1995; 12(1-2): 114-18.

20. Nagata S, Morioka T, Matsukado K, Natori Y, Sasaki $\mathrm{T}$. Retrospective analysis of the surgical treated temporal lobe arteriovenous malformations with focus on the visual field defects and epilepsy. Surg Neurol. 2006; 66(1): 625-7.

21. Husain AM, Mendez M, Friedman AH. Intractable epilepsy following radiosurgery for cerebral arteriovenous malformation. J Neurosurg. 2001; 95(5): 888-92.

22. Schauble B, Cascino GD, Pollock BE, Gorman DA, Weigand S, Cohwen-Gadol AA et al. Seizures autcomes after stereotactic radiosurgery for cerebral arteriovenous malformations. Neurology. 2004; 63(4): 683-7.

23. Hoh BL, Chapman PH, Loefller JS, Carter BS, Ogilvy CS. Results of multimodality treatment for 141 patients with brain arteriovenous malformations and seizure. Neurosurgery. 2002; 51(2): 303-11.

24. Przybylowski CJ, Ding D, Starke RM, Yen CP, Quigg M, Dodson B, et al. Seizure and anticonvulsant outcomes following stereotactic radiosurgery for intracranial arteriovenous malformations. J Neurosurg. 2015; 122 (6): 1299-305.

25. Arslan I, Tezcanli E, Yilmaz M, Cizmeli O, Sengoz M, Peker S. Gamma knife radiosurgery for arteriovenous malformations: Clinical Series of 199 Patients. Turk Neurosurg. 2017; 27(2): 301-8.

26. Koltz MT, Polifka AJ, Saltos A, Slawson RG, Kwok Y, Aldrich EF, et al. Longterm outcome of Gamma Knife stereotactic radiosurgery for arteriovenous malformations graded by the Spetzler-Martin classification. J Neurosurg. 2013; 118(1): 74- 83.

27. Ding D, Starke RM, Quigg M, Yen CP, Przybylowski CJ, Dodson BK, et al. perebral arteriovenous malformations and epilepsy, Part 1: predictors of seizure Presentation. World Neurosurg. 2015; 84(3): 645-52.

28. Ironside N, Chen CJ, Ding D, Ilyas A, Kumar JS, Buell $\mathrm{TJ}$, et al. Seizure Outcomes After Radiosurgery for Cerebral Arteriovenous Malformations: An Updated Systematic Review and Meta-Analysis. World Neurosurg. 2018; 120: 550-62. 